\title{
NEW RELIEFS FROM VEII AND MITHRAIC RELIEFS FROM ETRURIA (REGIO VII): ICONOGRAPHY, CHRONOLOGY AND ARCHAEOLOGICAL CONTEXT
}

\begin{abstract}
Summary: This paper discusses the Mithraic reliefs found in Etruria (Regio VII). The reliefs are analysed and their iconographic, archaeological and chronological features compared with a view to advancing new proposals on the cult of Mithras in the area concerned. The paper focuses first on the new Mithraic relief discovered in Veii and discusses the presence of a specific object that constitutes the most original iconographic feature of the relief. It can be seen aligned behind Mithras' head, which obscures its central part: considering its shape and the presence of the quiver over Mithras' right shoulder, the object can be identified as a bow. The object's specific position, probably connected to the symbolic importance of the bow in the mysteries of Mithras, is unique not only among Mithraic reliefs but also in the surviving Mithraic evidence from the Roman world. The other reliefs from Etruria are analysed, with a brief description of the type of iconography, the chronology and archaeological context of each piece. Comparing the reliefs allows us to pinpoint differences in size, style and chronology, highlighting the uniqueness of the new relief from Veii. These differences can be put down to factors that are yet to be examined in more detail, connected to the clients and the workshops operating in the region. The study concludes that the Veii relief can be considered not only the oldest and most stylistically refined of these pieces, but also one of the earliest attestations of the cult of Mithras in Etruria.
\end{abstract}

Key words: Etruria, Veii, Mithraic reliefs, iconography, chronology, archaeological context

\section{INTRODUCTION $^{1}$}

The recent archaeological discoveries of Mithraic artefacts at Tarquinia, with the exceptional marble statue group, and at Veii, with the extraordinary marble relief from the plateau, have refocused scholarly attention on the diffusion of this mystery cult in

${ }^{1}$ I would like to thank the organizers of the Symposium Peregrinum 2016, professors Patricia A. Johnston, Attilio Mastrocinque, and László Takács; I also wish to mention Dr. F. Boitani, Prof. G. Sfameni Gasparro and Prof. Eugenio La Rocca for their advice, Dr. I. Van Kampen, director of the Nuovo Museo dell'Agro Veientano, for facilitating my documentary research, and G. Pelucchini, S. Bossi and N. Luciani for their help. 
Etruria, as also demonstrated by the various papers on this topic in this Conference Volume. ${ }^{2}$ The present study is structured as follows: a brief introduction to the most recent discoveries, consisting of two reliefs discovered at different times on the plateau of the city of Veii, already published ${ }^{3}$ but on which some further considerations are offered. There follow some general remarks on known reliefs found in Etruria (Regio VII). Finally, the paper concludes with a comparative analysis of the principal chronological and stylistic/artistic features of all of the Mithraic reliefs from this area. A comprehensive comparative study of these finds is still lacking, and though it is clear that a fuller understanding of their stylistic features would require a more wideranging comparison with other Mithraic artefacts, especially from Rome itself, ${ }^{4}$ the paper nonetheless attempts to pinpoint some of the characteristics of this specific class of artefacts.

\section{MITHRAIC RELIEFS FROM VEII}

Until a few years ago, and more specifically until 2009, no evidence for the cult of Mithras was known in the Roman city of Veii, ${ }^{5}$ in marked contrast to the attestations from its immediate vicinity: Rome to the south and the areas of Cerveteri, Fiano Romano and Capena to the north (fig. 1). This suspect gap has now been filled by the discovery of two reliefs on the plateau of the city. The first, composed of two pieces (A and B), is on display in the Nuovo Museo dell'Agro Veientano in Palazzo Chigi, in the town of Formello ${ }^{6}$ (fig. 2). This relief has already been published by the present author and the paper will therefore focus only on some specific aspects, referring readers to my earlier study for a more detailed discussion (fig. 3). Although this relief features the typical bull-slaying scene (tauroctony), it differs from other similar finds for its high stylistic quality and the presence of an iconographic feature that is rare among other existing Mithraic reliefs. The two pieces of the relief were found on separate occasions in the same field, located in the northern part of the Campetti area on a gentle downward slope towards the Valchetta stream near the periphery of the Roman city of Veii (fig. 4). It is made from a single slab of white, fine-grained marble

${ }^{2}$ See for example the papers by dott.ssa M.G. Scapaticci (DOI: 10.1556/068.2018.58.1-4.2), prof.ssa R. Rubio Rivera (DOI: 10.1556/068.2018.58.1-4.4) and dott. N. Luciani (DOI: 10.1556/068. 2018.58.1-4.3). Still fundamental on the spread of the cult of Mithras in Etruria is CUMONT, F.: Mithra en Étrurie. In In PARIBENI, R. (ed.): Scritti in onore di Bartolomeo Nogara: raccolti in occasione del suo LXX anno. Città del Vaticano 1937, 95-103 whilst the most recent study to collect, analyse and up-date all the data is by LUCIANI, N.: Mitra in Etruria. Roma 2015-2016 (undergraduate thesis).

${ }^{3}$ FusCO, U.: New Evidence Relating to the Cult of Mithras in Southern Etruria: the case of Veii (Rome). Archeologia Classica 66, n. s. II 5 (2015) 519-546.

${ }^{4}$ For a study of the relationship between artisanal production and the urban economy, HAWKINS, C.: Roman Artisans and the Urban Economy. Cambridge 2016.

${ }^{5}$ See for example the historical and archaeological overview in LIVERANI, P.: Municipium Augustum Veiens. Veio in età imperiale attraverso gli scavi Giorgi (1811-13). Roma 1987.

${ }^{6}$ Relief: n. 143672. 


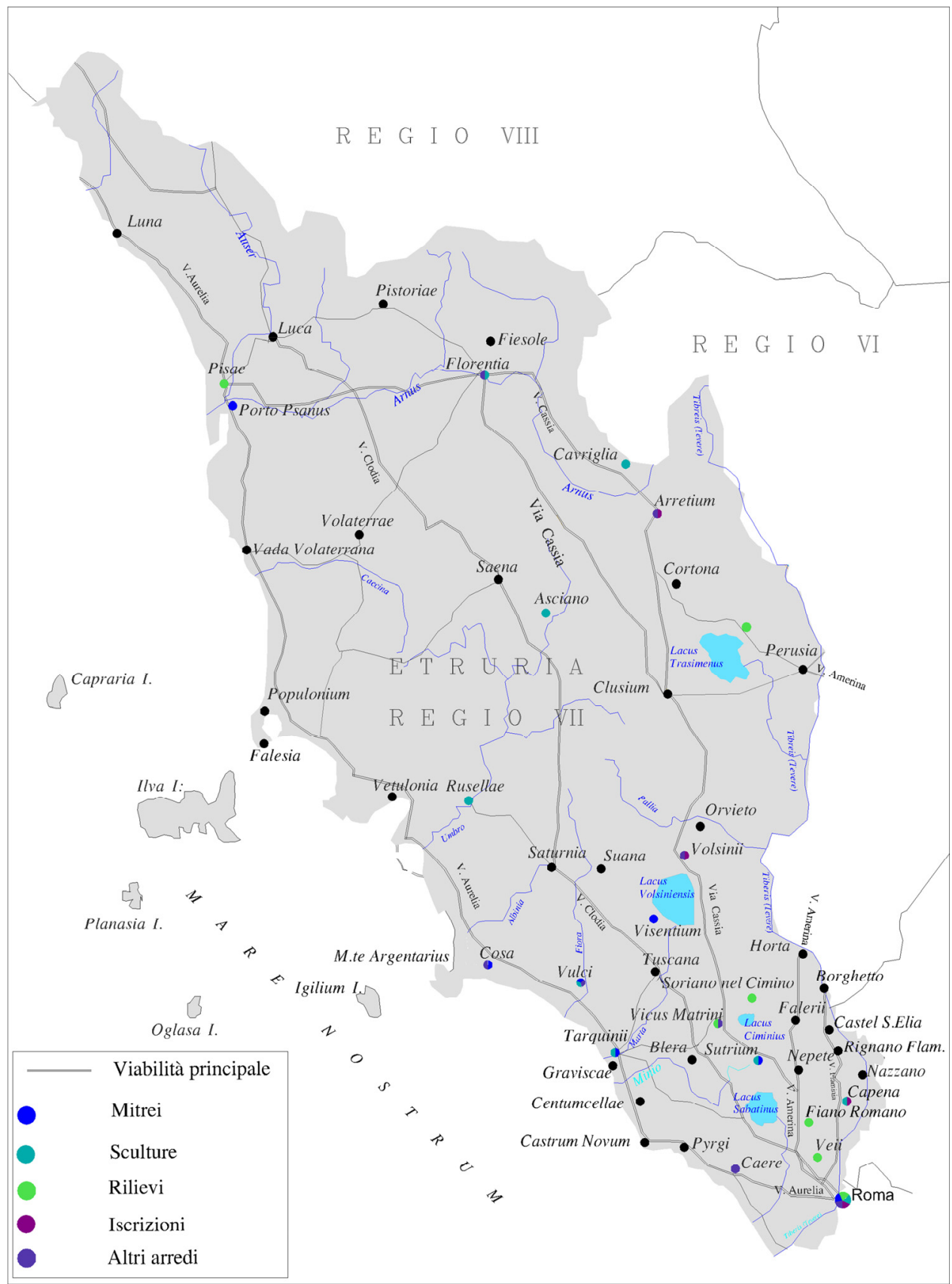

Fig. 1. Map showing the distribution of Mithraic finds in Etruria (Regio VII) (from LuCIANI, N.: Mitra e l'Etruria. In Vulci e i misteri di Mitra. Culti orientali in Etruria. Catalogo della mostra. Montalto di Castro 2016). 


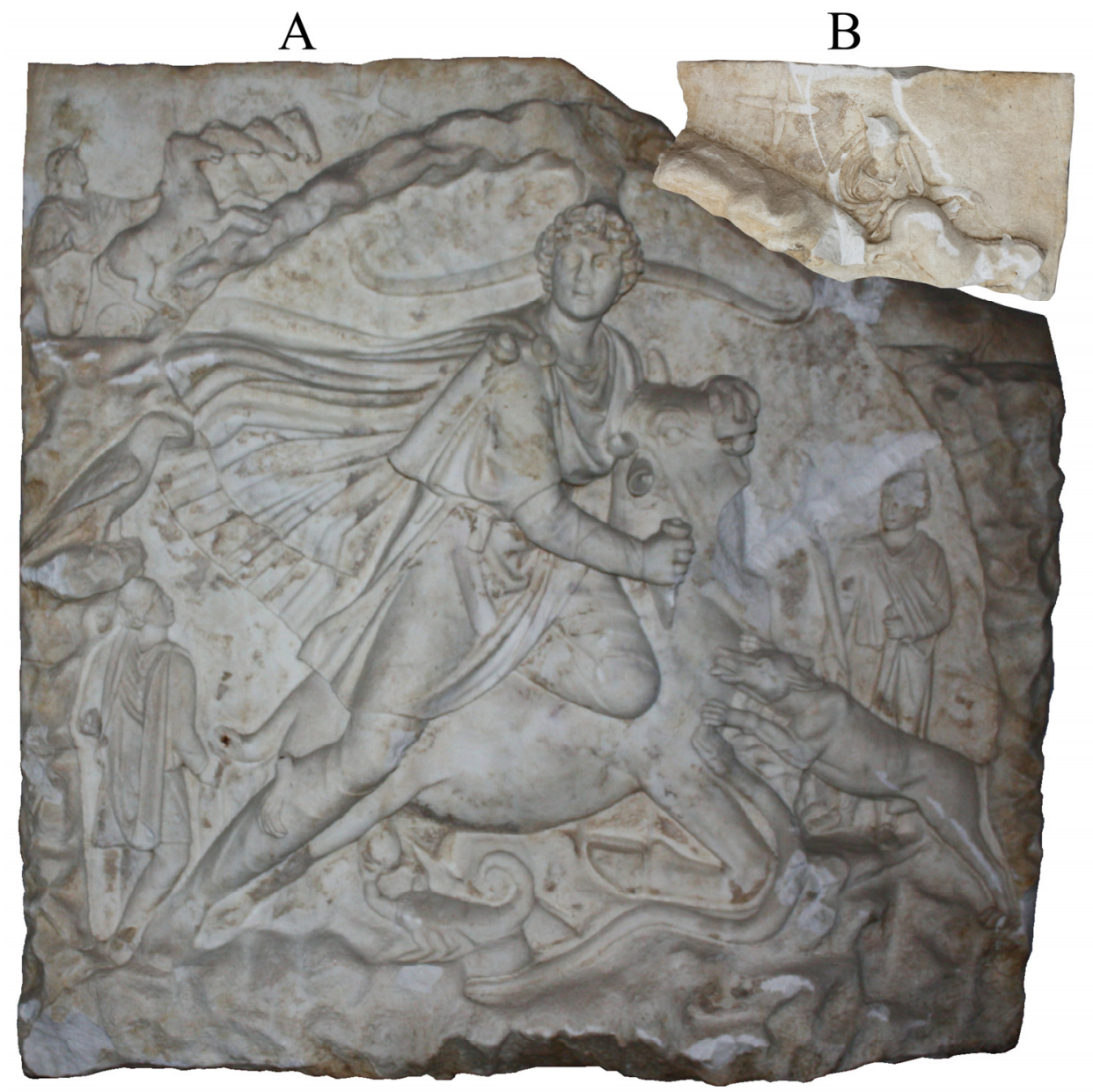

0

$0.5 \mathrm{~m}$

Fig. 2. Photo mosaic of the two finds A-B (photos taken by the author).

probably identifiable as Luni marble. ${ }^{7}$ We will begin the description of the find starting from the central scene, depicting the slaying of the bull by the god Mithras, who dominates the representation, being much taller than the other figures (almost twice the size). The idealized face of the god is turned towards the viewer: he wears a tunica manicata, a Phrygian cap, which is only partially visible due to a crack in the marble, and anaxyrides. Around his shoulders is a billowing cloak with numerous folds held

${ }^{7}$ I thank prof. F. Guidobaldi for providing me with this information on the type of marble. There are no visible traces of colour on the surface. 

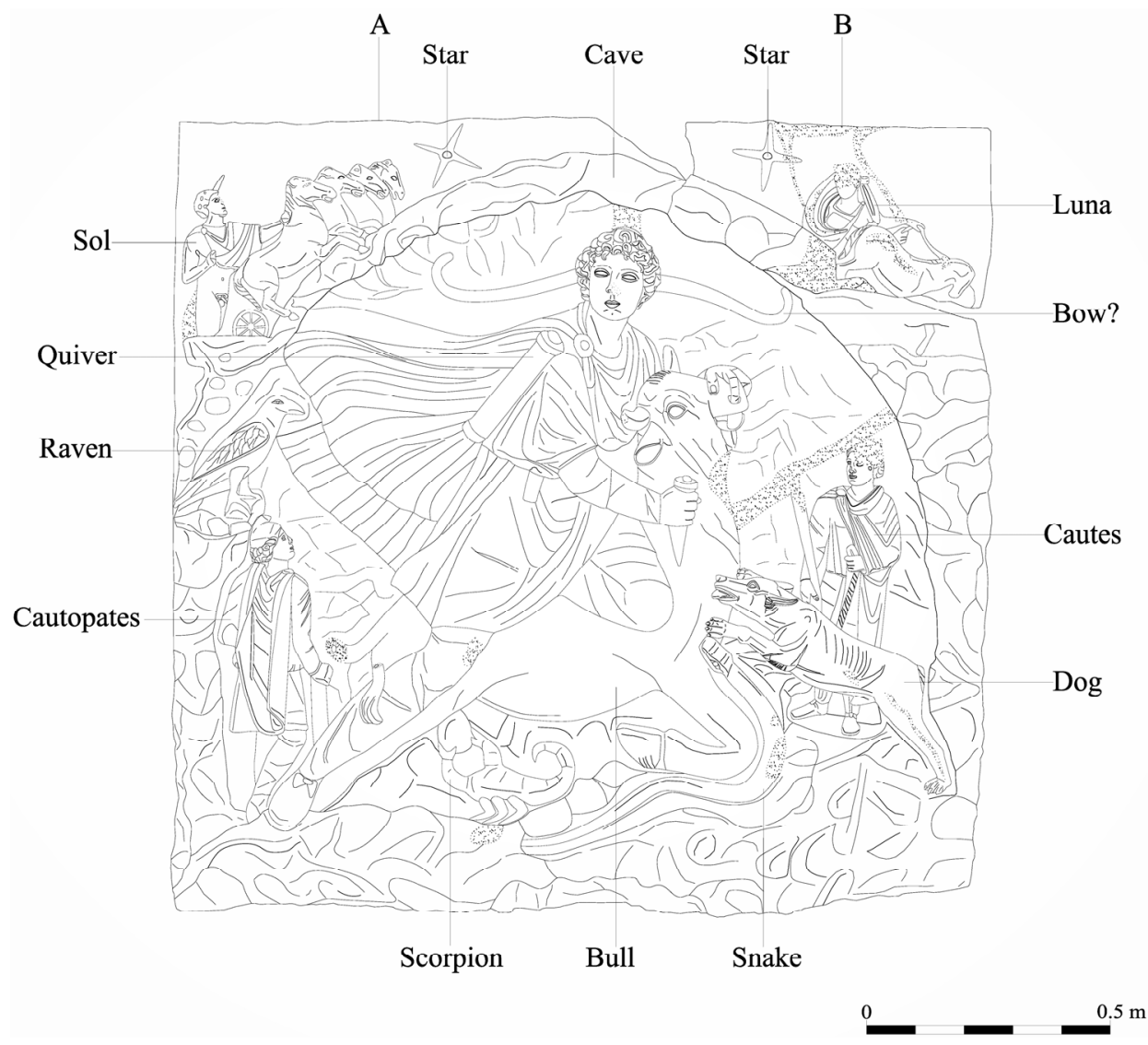

Fig. 3. Drawing of the relief; the dots indicate damaged areas (drawing by the author).

in place by a circular fibula on his right shoulder; over the same shoulder he carries a quiver. ${ }^{8}$ The torchbearers (dadophori) are smaller than Mithras and dressed in a similar way. Cautopates is seen on the viewer's left. He grasps something in his right hand, presumably his lowered torch, and only his right leg is bent ${ }^{9}$ (fig. 5). Cautes is on the right, facing us with his head in three-quarter profile to look at the god. He holds his torch up with his right hand while his left arm is bent and covered by his cloak. His legs are straight and he has two objects in his left hand: the first is wider (perhaps a second torch?) and the other thinner and decorated with a series of incisions ${ }^{10}$ (a baton or pedum?) (fig. 6). The sequence of figures represented on this relief is Cautopates $\rightarrow$ Mithras $\rightarrow$ Cautes, an ordering of the torchbearers that can be defined as the northern

${ }^{8}$ C. DE LA Berge in Le Dictionnaire des Antiquités Grecques et Romaines de Daremberg et Saglio IV (1877-1919) 427, s.v. Pharetra.

${ }^{9}$ FUSCO: New Evidence (n. 3) 529.

${ }^{10}$ FusCO: New Evidence (n. 3) 529. 


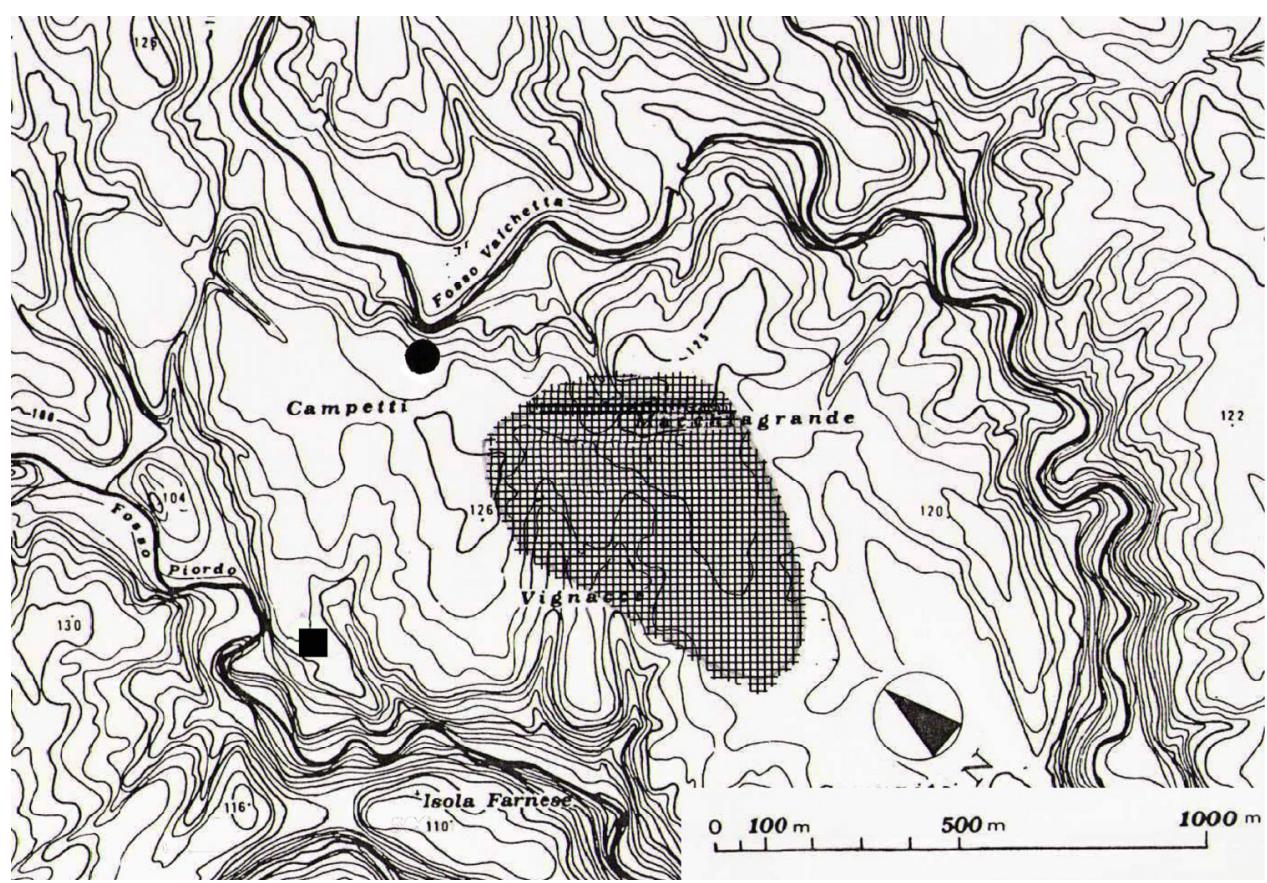

Fig. 4. Map with areas indicating where the relief was discovered (circle) and the location of the southwest Campetti site (square). The area marked by crosshatching indicates the probable extent of the town of Veii in the Imperial period (reworking from LIVERANI [n. 5] 23, fig. 4).

type based on evidence from the Roman provinces in the north and that is widely documented. ${ }^{11}$ On the upper left-hand part of the relief we see Sol, wearing a radiate solar crown, on his chariot drawn skywards by four horses. ${ }^{12}$ At the top of the relief are two four-pointed stars ${ }^{13}$ and then, on the right-hand side, Luna with her robes blowing in the wind to reveal one of her breasts. She is also aboard her biga, drawn downwards by two horses, and looks towards Mithras. ${ }^{14}$ Reading this arrangement vertically, the relief presents an iconographical connection between Cautopates - Sol star on the left and Cautes - Luna - star on the right. ${ }^{15}$ The depiction of Sol and Luna on chariots in place of simple busts is currently unique among the Mithraic reliefs of Etruria. Finally, the scene inside the cavern is completed by animals portrayed in great anatomical detail. ${ }^{16}$

${ }^{11}$ FUSCO: New Evidence (n. 3) 529-530.

${ }^{12}$ FUSCO: New Evidence (n. 3) 527.

${ }^{13}$ For an interpretation of the two stars in relation to the torchbearers (dadophori), FUSCO: New Evidence (n. 3) 530-531.

${ }^{14}$ FUSCO: New Evidence (n. 3) 527.

${ }^{15}$ FUSCO: New Evidence (n. 3) 529-530.

${ }^{16}$ FUSCO: New Evidence (n. 3) 531. 


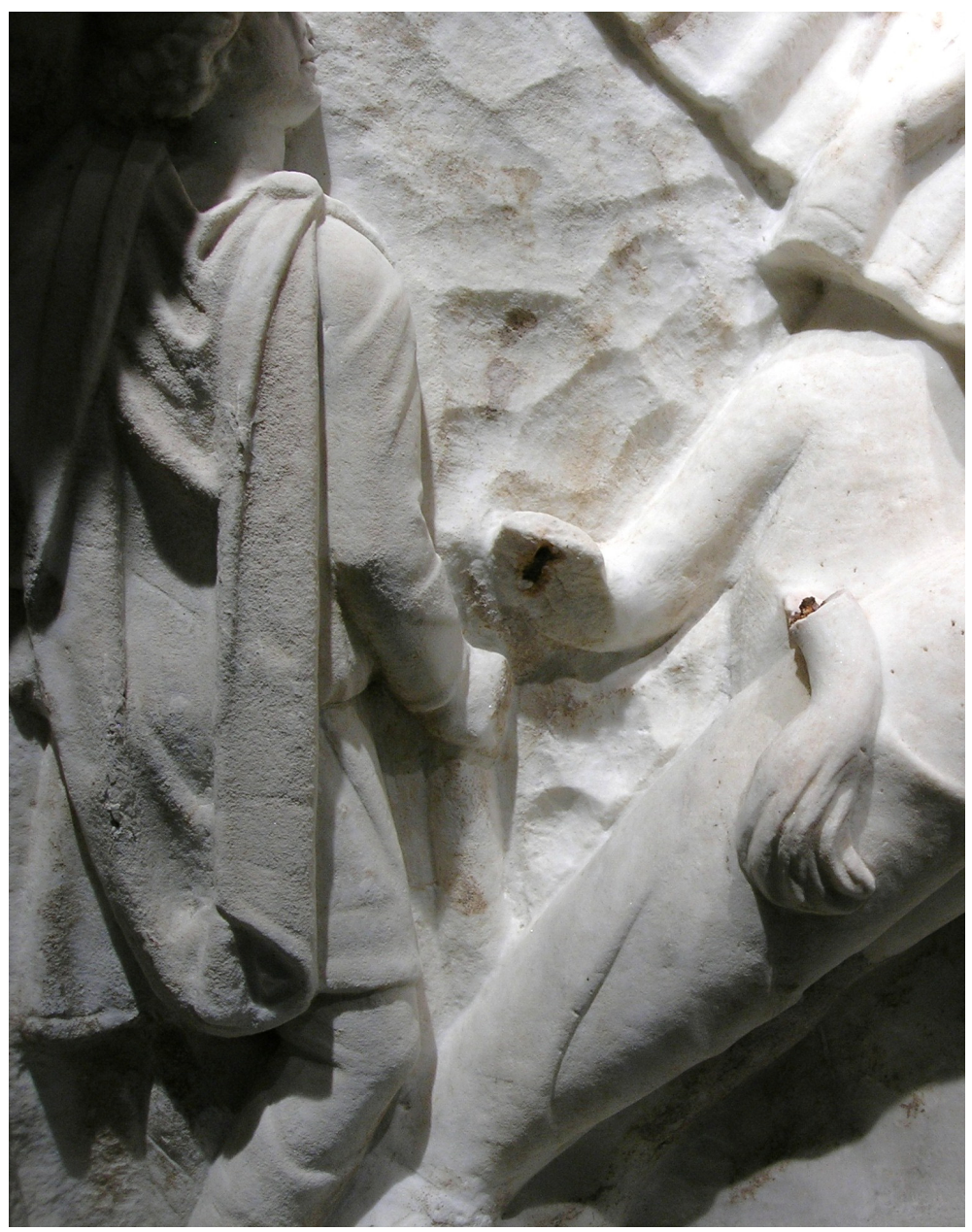

Fig. 5. Cautopates (photo taken by the author).

One final object, the most original iconographic feature of the relief, remains to be described. It can be seen aligned behind Mithras' head, which conceals the central part of the object. It is long with curved ends and is positioned at the back of the cavern as though hanging from the wall (fig. 7). Considering its shape and the presence of the quiver over Mithras' right shoulder, we could identify it as a bow, an item frequently found in Mithraic iconography and linked to various characters. ${ }^{17}$ Mithras has a bow when he is presented as a hunter or when associated with the so-called "watermiracle", and in numerous other situations.

The association of a bow and a quiver in a bull-slaying scene can also be found in another marble relief - CIMRM 546 - where we see two objects behind the god,

${ }^{17}$ FusCO: New Evidence (n. 3) 531-534. 


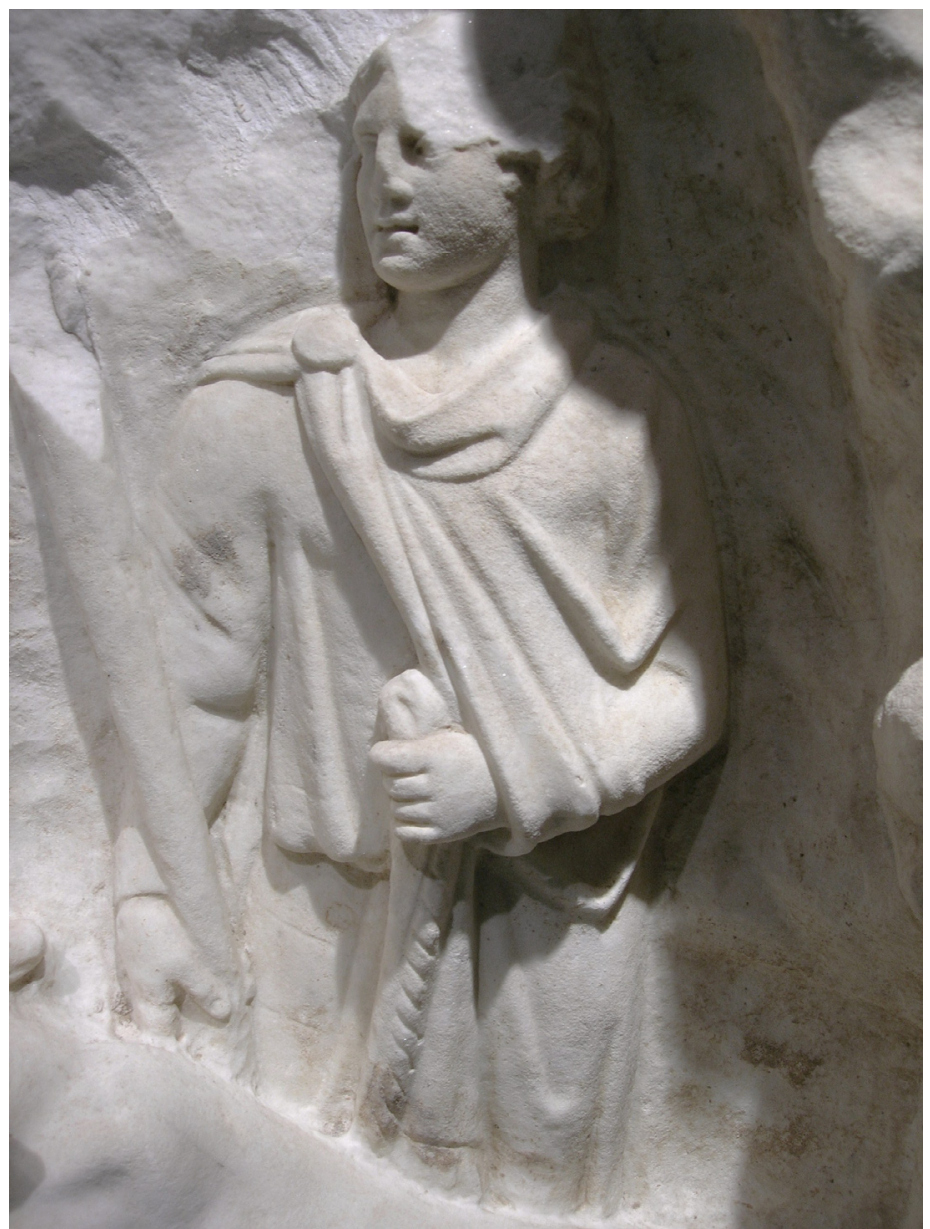

Fig. 6. Cautes (photo taken by the author).

just above his cloak. Though only partially visible, these two objects have been unanimously identified by scholars as a quiver and a bow. ${ }^{18}$ However, the specific position of the bow inside the cavern on the relief from Veii is unique, and has no parallels in other Mithraic reliefs or archaeological finds: a variety of different objects are depicted above Mithras' head but not in the same position as the object under consideration here. ${ }^{19}$ We can thus say that the sculptor (and therefore whoever commissioned

${ }^{18}$ CUMONT, F.: Textes et monuments figurés relatif aux mystères de Mithra [MMM] I-II. Bruxelles 1896-1899, 211; AMELUng, W.: Die Sculpturen des vaticanischen Museums im Autrage und unter Mitwirkung des Kaiserlich Deutschen Archäologischen Instituts (Römische Abteilung) II. Berlin 1903-1956, 178-179; R. VOLLKOMMER in LIMC VI.1 (1992) 601 nr. 150, s.v. Mithras.

${ }^{19}$ See for example: CIMRM 40, where above the head of Mithras we see the bust of a bearded god (Saturn-Serapis); CIMRM 2198 with the lion's head above Mithras' head and finally the painting in the Mitreo Barberini, CIMRM 390, with the depiction of the god Aion above the slaying of the bull. 


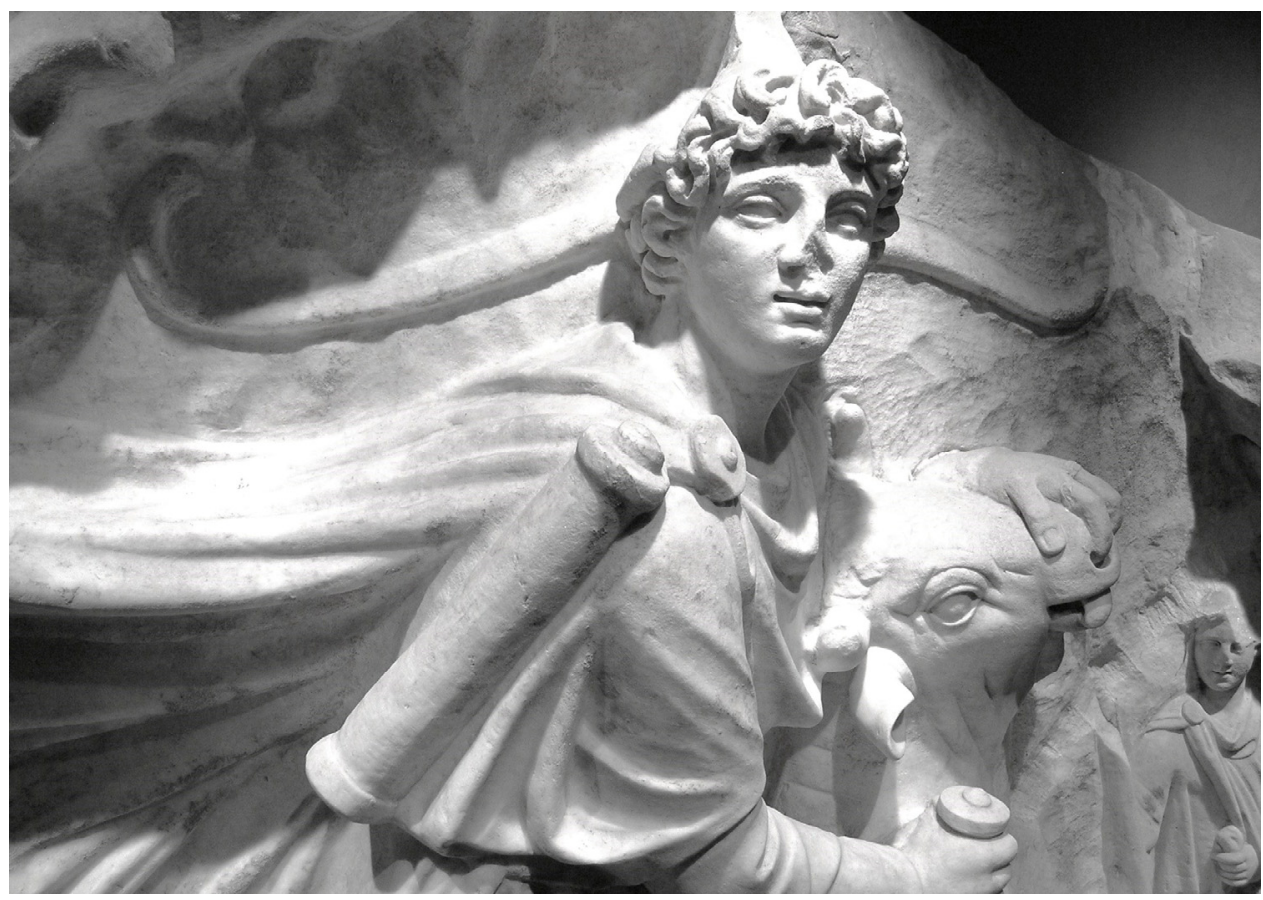

Fig. 7. Detail of the object (a bow?) behind Mithras' face (photo taken by the author).

the relief) undoubtedly meant to confer particular prominence on this object by portraying it separately and in perfect symmetry with the head of the god. The special attention reserved for the representation of this object is probably also explained by the symbolic importance of the bow in the mysteries of Mithras. R. Beck has recently highlighted the symbolic significance of this object as "opposition and polarity": 20 in an iconographic analysis of a series of figures depicted on a cult vessel, discovered in a Mithraeum in Mainz and datable to the first quarter of the 2nd century AD, he identifies a seated figure in the act of firing an arrow at another figure as the Father of the Mithraic community, initiating a candidate. In so doing, the Father imitates the mythic archery of Mithras at the so-called "water miracle". ${ }^{21}$ Thus, according to Beck, "the scene on the cup is both cult initiation and water miracle... Ritual is here a mimesis of myth". ${ }^{22}$ Both ritual and myth in this case embody the principle of "harmony of tension in opposition", encapsulated by a quotation from Porphyry's De antro nympharum 29: "And so there is a tension of harmony in opposition, and it shoots

${ }^{20}$ BeCK, R.: Ritual, Myth, Doctrine, and Initiation in the Mysteries of Mithras: New Evidence from a Cult Vessel. JRS 90 (2000) 145-180 and BECK, R.: The Religion of the Mithras Cult in the Roman Empire. Mysteries of the Unconquered Sun. Oxford - New York 2006, 6, 11, 81-85.

${ }^{21}$ BECK: Ritual (n. 20).

${ }^{22}$ BECK: Ritual (n. 20) 150 and fig. 1. 
from the bowstring through opposites". ${ }^{23}$ Beck interprets the "harmony of tension in opposition" as the second axiom of the cult and therefore an important principle of Mithraic doctrine. This concept of opposition and polarity is evident in the iconography of Cautes and Cautopates, while it is more veiled in that of other objects such as the bow. According to Beck, the bow thus symbolises opposition, both with regard to the aforementioned metaphor ("... and it shoots from the bowstring through opposites") and to its visual representation. ${ }^{24}$ Finally, we could develop R. Beck's interpretation by suggesting that the artist who made the relief, and thus his client, may have wished to combine two key moments of the Mithraic creation myth, demiurgic and cosmogonic: the water-miracle (alluded to by the bow) and the bull-slaying scene. ${ }^{25}$

At present it is impossible to establish with certainty if the relief in question was made on site or commissioned and then transported to the shrine of Veii on completion. The high stylistic quality and refined workmanship of the piece lead us to believe that the relief was most likely an important commission entrusted to a workshop in Rome. ${ }^{26}$ Its date can only be estimated on the basis of its stylistic features as the original archaeological context is unknown. A preliminary comparison with other reliefs dated to around the 2 nd century AD suggests that it belongs to the same period. $^{27}$ The stylistic features of Mithras' face can be compared to those of a marble sculpture of a young boy's head from Trajan's Forum dated to the Antonine period ${ }^{28}$ (fig. 8); equally, the treatment of the hair in the form of waves separated by the drill, which sometimes cuts deep and at others remains on the surface, can be seen in another statue of the Antonine period, that of Cybele seated on her lion at Villa Doria Pamphilj in Rome. ${ }^{29}$ Furthermore, the sculptural quality of the drapery of Mithras' cloak and clothes can be likened to that of some sarcophagi dating from 140-150 AD to $160-170 \mathrm{AD} .^{30}$ In conclusion, we are inclined to date the relief to the middle of the 2nd century AD, during the late Hadrianic/early Antonine period.

The two pieces of the relief were found on separate occasions in the same field, located in the north Campetti area on a slight downward slope towards the Valchetta stream near the edge of the Roman city of Veii, but outside the city limits (fig. 4). There are neither emerging wall structures visible on the ground nor geological layers of tuff in this field, which is now used to grow alfalfa. At the current state of knowledge

${ }^{23}$ Translation by BECK: The Religion (n. 20) 82-83.

${ }^{24}$ BECK: Ritual (n. 20) 168, see also 170-171.

${ }^{25}$ I thank prof.ssa G. Sfameni Gasparro for proposing this idea and her willingness to discuss some interpretations of the work.

${ }^{26}$ On the organization of the various types of artisans, particularly those dedicated to sculpture, and the economic life of the city see most recently HAWKINS (n. 4) 79-101 and especially 95. It is also worth remembering the discovery in a secondary context of the votive dedication, unfortunately fragmentary, of a marmorarius from the bath and healing complex of Campetti, in the south-west area of Veii: FUSCO, U.: Nuovi reperti dall'area archeologica di Campetti a Veio. Archeologia Classica 52, n.s. 2 (2001) 268-270.

${ }^{27}$ FUSCO: New Evidence (n. 3) 535 and n. 90.

${ }^{28}$ ARATA, F. P.: Una testa giovanile dal Foro di Traiano: copia, rielaborazione o originale d'epoca imperiale? BCAR 112 (2011) 119-128.

${ }^{29}$ PALMA, B.: Una statua di Cibele seduta sul leone a Villa Doria Pamphilj. Studi Miscellanei 22 (1974-1975) 141-147. I wish to thank prof.ssa B. Palma for bringing this parallel to my attention.

${ }^{30}$ FUSCO: New Evidence (n. 3) 536 and n. 92. 


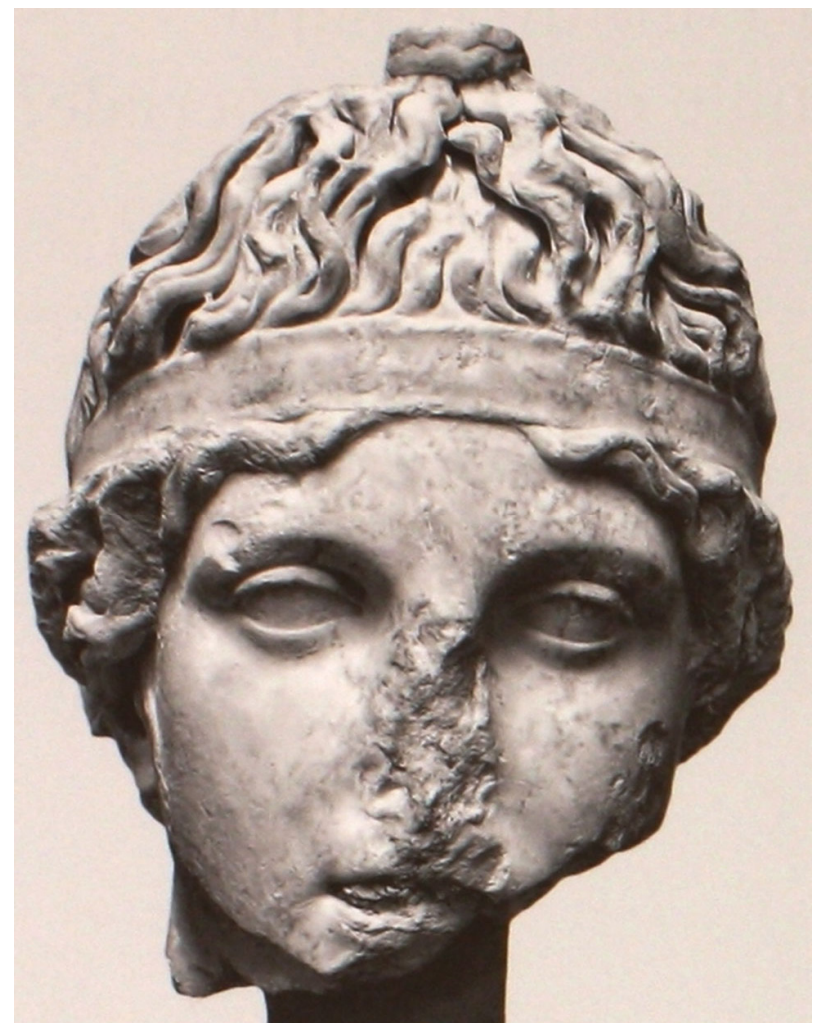

Fig. 8. Detail of the head from the Forum of Traian. Image of Victoria, or personification of a provincia or nation, second quarter of the 2 nd century $\mathrm{AD}$ (from ARATA: Una testa [n. 28] fig. 1).

it is therefore very difficult to determine where the relief originally came from and thus, in essence, to locate the Mithraic shrine (spelaeum-cavern). However, two plausible hypotheses can be proposed. The first is that the relief belonged to a Mithraic shrine (spelaeum-cavern) situated in one of the archaeological areas discovered by $\mathrm{J}$. Ward-Perkins during his survey on the plateau of the city during the last century and recently published by the British School at Rome (areas 20, 21 and 28 are those nearest to the findspot and are interpreted as a private or public building; fig. 9). A second theory is that the relief came from a shrine in another more distant archaeological site on the Veii plateau; in this case the most suitable archaeological location for a Mithraic shrine would be the south-west area of the Campetti site, about $600 \mathrm{~m}$ southwest of the relief's findspot and interpreted as a thermal, therapeutic and sacred site with springs ${ }^{31}$ (fig. 4). The first theory currently seems more plausible, considering also the weight of the relief (around $1500 \mathrm{~kg}$ ).

${ }^{31}$ FusCO, U.: Aspetti cultuali e archeologici del sito di Campetti, area sud-ovest, dall'età arcaica a quella imperiale. RPAA (s. III) 86 (2013-2014) 309-345. 


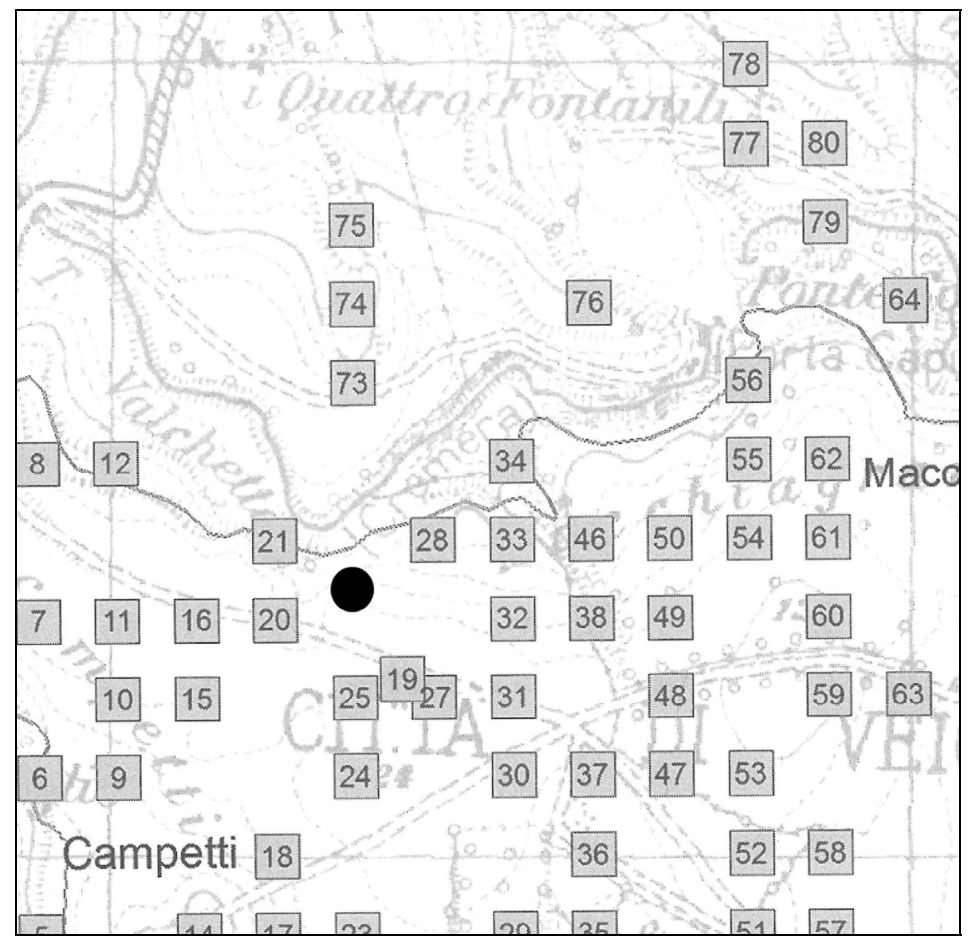

Fig. 9. Map of the area where relief was found (black circle) and archaeological sites identified by J. Ward-Perkins (reworking from CASCINO - Di GIUSEPPE - PATTERSON: Veii [n. 32] 32, fig. 4.1).

The second relief from Veii was discovered during the survey carried out by J. Ward-Perkins: the artefact is described in the recent publication of the British School and was found in area 37 (fig. 9), about $200 \mathrm{~m}$ from the findspot of the first relief. Unfortunately, little information is available on this find; the text of the publication reads: "Il rinvenimento di una lastra di terracotta architettonica e di un bassorilievo di marmo vanno riferiti ad un edificio pubblico verosimilmente di carattere cultuale. La lastra di marmo reca resti di figurine tipiche del ciclo dedicato a Mitra (trad. The marble slab has remains of the typical figures of the cycle dedicated to Mithras)." ${ }^{, 32}$ Unfortunately, no information is currently available on the chronology of this piece nor do we have images of it. ${ }^{33}$ In conclusion, it is impossible to say with any certainty whether this find belonged to the same Mithraic shrine (spelaeum-cavern) as the previous relief or to a different one, opening up the possibility that there may have been a second shrine in Veii.

${ }^{32}$ Di GiUSEPPE, H. - PATTERSON, H. L.: Area 37. Età romana. In CASCino, R. - Di GiusePPE, H. Patterson, H. L. (eds): Veii. The Historical Topography of the Ancient City. A Restudy of John Ward Perkins's Survey [Archaeological Monographs of the British School at Rome 19]. London 2012, 50-51.

${ }^{33}$ I personally searched the storeroom of British School at Rome and thank Prof. C. Smith and Dr. R. Cascino for their help. 


\section{MITHRAIC RELIEFS DOCUMENTED IN ETRURIA}

A total of eight Mithraic reliefs are documented in Etruria (Regio VII), including those discovered in Veii, almost all of which come from Southern Etruria, like the majority of the Mithraic archaeological evidence in general (fig. 1). From an iconographic point of view, all the reliefs feature the same scene but with slight variations, as is generally true of the artistic production of the Roman period (fig. 10).

\begin{tabular}{|c|c|c|c|c|}
\hline $\mathrm{n}$. & $\begin{array}{l}\text { Location of } \\
\text { discovery }\end{array}$ & Material & Dimensions & Chronology \\
\hline 1 & $\mathrm{Veii}^{34}$ & white marble & $\begin{array}{l}1.55 \times 1.54 \times 0.16- \\
0.33 \mathrm{~m}\end{array}$ & $\begin{array}{l}\text { middle of the 2nd } \\
\text { century } A D\end{array}$ \\
\hline 2 & Veii $^{35}$ & white marble & $?$ & Imperial period? \\
\hline 3 & Fiano Romano $^{36}$ & white marble & $0.67 \times 0.62 \times 0.16 \mathrm{~m}$ & $\begin{array}{l}\text { second half of the } \\
\text { 2nd century AD }\end{array}$ \\
\hline 4 & Sutri $^{37}$ & marble & $\begin{array}{l}1.07 \times 0.63 \times 0.025- \\
0.03 \mathrm{~m}\end{array}$ & late Roman? \\
\hline 5 & Vicus Matrini ${ }^{38}$ & peperino & $1.13 \times 0.86 \mathrm{~m}$ & late Roman? \\
\hline 6 & Soriano in Cimino ${ }^{39}$ & white marble & $0.62 \times 0.58 \mathrm{~m}$ & $\begin{array}{l}3 \text { rd }-4 \text { th century } \\
\mathrm{AD}\end{array}$ \\
\hline 7 & $\mathrm{Pisa}^{40}$ & white marble & $0.55 \times 0.44 \mathrm{~m}$ & $\begin{array}{l}\text { late } 2 n d-3 r d \\
\text { century AD }\end{array}$ \\
\hline 8 & $\begin{array}{l}\text { Unknown, from } \\
\text { Etruria }^{41}\end{array}$ & marble & $0.50 \times 0.68 \times 0.09 \mathrm{~m}$ & late Roman \\
\hline
\end{tabular}

${ }^{34}$ FUSCO: New Evidence (n. 3).

${ }^{35}$ Di GIUSEPPE - PATTERSON: Area 37 (n. 32).

${ }^{36}$ CIMRM 641(= VOLKOMMER: Mithras [n. 18] nr. 136, 436).

${ }^{37}$ CIMRM 654; MoRSELLI, C.: Sutrium [Forma Italiae, Regio VII, 7]. Firenze 1980, 43, nr. 143.

${ }^{38}$ CIMRM 655-656; ANDREUSSI, M.: Vicus Matrini [Forma Italiae, Regio VII, 4]. Roma 1977, 69, nr. 170. This relief is the only one with an inscription: CIMRM 656 = CIL XI 3320: L(ucius) Avillius Rufinus posuit.

${ }^{39}$ CIMRM 657; SCARDozzI, G.: Ager Ciminius: (IGM F 137 II NO Soriano nel Cimino, II SO Vignanello) [Carta archeologica d'Italia. Contributi]. Viterbo 2004, 59.

${ }^{40}$ CIMRM 663(= VOLKOMMER: Mithras [n. 18] nr. 128); GENOVESI, S.: Nuove evidenze per il culto di Mitra dall'area di Portus Pisanus/S. Stefano ai Lupi (LI). In FACCHIN, G. - MiLleTTI, M. (a cura di): Materiali per Populonia 10 (Quaderni del Dipartimento di archeologia e storia delle arti, Sezione archeologica, Università di Siena). Pisa 2011, 285.

${ }^{41}$ MINTO, A.: Di alcuni bassorilievi tardo-romani del Museo Archeologico di Firenze. In Hommages à Joseph Bidez et à Franz Cumont [Collection Latomus II]. Bruxelles 1949, 207, nr. 1; CIMRM 668. 


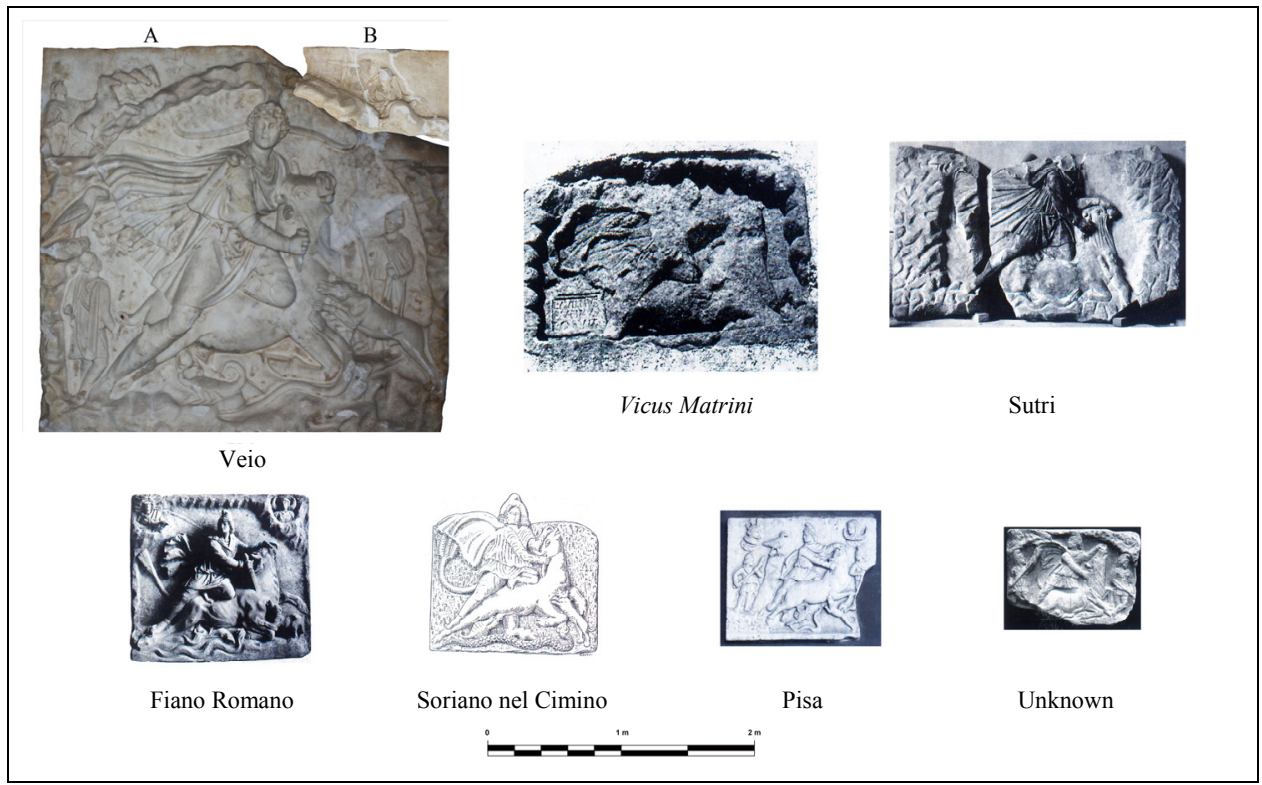

Fig. 10. Overview of the Mithraic reliefs discovered in Etruria (Regio VII): Veii (photo taken by the author); Vicus Matrini (from ANDREUSSI: Vicus Matrini [n. 38] 69, fig. 123), Sutri (from CIMRM 654, fig. 183), Fiano Romano (from CIMRM 641, fig. 179), Soriano nel Cimino (from CIMRM 657, fig. 184),

Pisa (from GENOVESI: Nuove evidenze [n. 40] 285, fig. 7), unknown place (from MiNTO: Di alcuni bassorilievi [n. 41] 207, nr. 1).

The order of the torchbearers (northern type) depicted on the relief from Veii differs from that on other finds from this area. The material from which the reliefs are made is generally marble with the exception of one (Vicus Matrini), which is made of peperino. It would of course be helpful to know the precise origin of the white marble from which the objects were made. All the reliefs were found outside their original context (spelaeum-cavern), and that from Sutri is the only find for which a connection with a sanctuary at the same location has been proposed with a degree of certainty. Maddalena Andreussi has suggested that the relief from Vicus Matrini may also belong to the same Mithraeum at Sutri. ${ }^{42}$ The size and chronology of the reliefs are indisputably useful factors for a comparative analysis. The size obviously affects the final cost and artistic quality of the piece: the dimensions are fairly uniform, with the exception of the relief from Veii which is by far the largest. In stylistic terms, the quality of production is somewhat uneven and indeed the relief from Soriano is thought to have been made by local artisans given its poor workmanship. The reliefs of the highest stylistic quality are without any doubt the first from Veii and those from Fiano Romano, but in this case too the relief from Veii is unique in terms of its size and stylistic refinement compared to the others. As regards the chronology, we must remember that, in light of the fact that the artefacts were found outside their original

\footnotetext{
${ }^{42}$ ANDREUSSI: Vicus Matrini (n. 38).
} 
context, the dating is based solely on stylistic criteria, with all the resulting limitations. The table presented above shows the chronological order of the reliefs; the date proposed here would make the first relief from Veii the most ancient of the Mithraic reliefs in Etruria. It could thus be considered as one of the earliest attestations of the cult of Mithras in Regio VII.

\section{CONCLUSION}

The iconography of the relief from Veii does not differ substantially from other known Mithraic artefacts, with the exception of the unusual positioning of the bow behind the head of the god which, according to the interpretation proposed here, holds a specific, symbolic importance. The high artistic quality and size of the relief indicate that the individual who commissioned it was of notable wealth and a member of the elite of the town of Veii. The question of which shrine the relief comes from remains unanswered, and no shrine has hitherto been located. The most likely hypothesis is that the shrine was located in the immediate vicinity of the relief's findspot.

\footnotetext{
Ugo Fusco

Sapienza University of Rome

Italy

ugo_fusco@tin.it
} 
